\title{
Identity Positionings in Squatters' Framings of Don Quijote Social Centre
}

\section{Don Kişot Sosyal Merkezi İşgalcilerinin Mekan Çerçevelerindeki Kimlik Konumlandırmaları}

\author{
İdil Atabinen ${ }^{1}$ (1), Göklem Tekdemir² (1)
}

'Social Psychology MA, Istanbul, Turkey ${ }^{2}$ Asst. Prof. Dr., Istanbul University, Faculty of Letters, Department of Psychology, Istanbul, Turkey

ORCID: I.A. 0000-0002-5725-6352;

G.T. 0000-0002-5988-4176

Corresponding author/Sorumlu yazar: İdil Atabinen,

Social Psychology MA, Istanbul, Turkey

E-mail/E-posta: i_atabinen@yahoo.com

Submitted/Başvuru: 30.03 .2020

Revision Requested/Revizyon Talebi:

11.05.2020

Last Revision Received/Son Revizyon:

05.07.2020

Accepted/Kabul: 08.07.2020

Published Online/Online Yayın: 14.12.2020

Citation/Atıf: Atabinen, I., \& Tekdemir, G. (2020). Identity positionings in squatters' framings of Don Quijote Social Centre.

Psikoloji Çalışmaları - Studies in Psychology, 40(2): 625-654.

https://doi.org/10.26650/SP2020-0040

\begin{abstract}
Studies on how to frame a political place render a broad perspective over identity making processes. Frames construct alternative realities based on the ideological culture (idioculture) of a movement and political place, and they position opposing and/or alternative identities within that place while setting the subject position of the narrator. This study deals with identity making within critical discursive psychology through the place frame of squatters who participated in Turkey's most famous and recent (open between 2013-2015) urban political squatting incident at the Don Quijote Social Centre in Kadiköy, Istanbul. An analysis of 13 semi-structured in-depth interviews with the actual participants of the squat yields results which illuminate opposite identity positionings (between opposing positions of organized and unorganized/anti-political individuals) and contradicting place frames. Categorized under three argumentative repertoires (squat as an alternative, an orderly place, and a space with limited ideology), the findings reveal how political action and place are politicized by focusing on different place frames which the participants rhetorically make based on their subject positions. While people make use of the same repertoire and are part of the same movement, they make framings in an opposing way in order to position themselves and others into certain subject positions. In conclusion, the present study focuses on in-group relations and identity making in this commoning incident. In the conclusion, arguments like the novelty of these kinds of movement that fall under the category of New Social Movements, their genuine alternativeness, the topics they introduce to the political arena and other ways of collective identity formation are debated upon.

Keywords: Place frames, discourse analysis, identity positioning, squatting
\end{abstract}




\section{ÖZ}

Politik mekanın nasıl çerçevelendiğine dair yapılan çalışmalar kimlik inşa sürecine geniş bir perspektif sağlar. Çerçeveler hareketin ve hareketin yürütüldüğü mekanın ideolojik kültürüne yönelik olarak alternatif gerçeklikler barındırır, mekandaki farklı ve/veya alternatif kimlikleri konumlandırır ve anlatıcının özne pozisyonunu görünür kılar. Bu çalışmada, Türkiye'nin son zamanlardaki en meşhur politik işgal örneği sayılan İstanbul Kadıköy'deki Don Kişot Sosyal Merkezi'ndeki (mekan 2013-2015 yılları arasında açık kalmıştır) işgalcilerin yaptığı mekan çerçevelerindeki farklı kimlik inşaları çalışılmıştır. İşgal evinde aktif olarak bulunmuş 13 kişiyle yarı-yapılandırılmış ve derinlemesine mülakatlar yapılmıştır. Görüşmeler eleştirel söylemsel psikoloji tekniğiyle analiz edilmiştir. Mekan içindeki farklı grupların birbirine zıt kimlik konumlandırmaları (örgütlüler ve örgütlü olmayanlar/anti-politikler arasında) ve farklı mekan çerçevelendirmeleri yaptıkları görülmüştür. Alıntılar Don Kişot Sosyal Merkez'e dair ortak üç açıklayıcı repertuvar (bir alternatif olarak işgal evi, düzenli bir yer, ideolojinin sınırlandığı alan) altında kategorize edilmiştir. $\mathrm{Bu}$ alıntılar politik eylemin kişiselliğini ve mekanın politikliğini aydınlatırken, katılımeıların kendi kimlik konumları ekseninde retorik olarak inşa ettikleri alternatif mekan çerçevelerini de göstermektedir. Ana sonuçlardan biri katılımcıların, aynı hareketin bir katılımcısı halindeyken ve aynı repertuvardan konuşuyorlarken bile kendilerini ve ötekileri belli özne pozisyonlarına konumlandırmak adına birbirine zıt çerçevelendirmeler inşa ettiğidir. Özetle bu çalışmada bir müşterekleştirme eylemindeki iç-grup ilişkileri ve dilsel kimlik inşa taktikleri ele alınmaktadır. Sonuç olarak, Yeni Sosyal Hareketler kategorisine giren bu tür hareketlerin yeniliğini tartışmak üzere ve bu hareketlerin hakiki alternatifleri, politik arenada gündeme getirdikleri konular ve diğer kolektif kimlik oluşturmanın başka yolları hakkında sorular sorulmaktadır.

Anahtar Kelimeler: Mekan çerçeveleri, söylem analizi, kimlik konumlandırma, işgal 
In social psychology notions like identity and subjectivity are so intertwined that they are almost impossible to separate while conducting a research on political action. Especially under social constructionist paradigm, studying those concepts through narratives, rich micro fields that clarify how self and identity are performed and constructed through talk (Benwell \& Stokoe, 2006; Sarbin, 1986), provides detailed proof to how closely and contextually constructed they are.

In daily conversations references of places are always visible; as places are settings to events (Sarbin, 2005). However, places may also operate as rhetorical tools for communicating relationships and different identities (Dixon \& Durrheim, 2000). Taylor (2010, p.15) shows the mutual interaction between places and individuals; that is, while people construct places, place positions its inhabitants. When people talk about a place, they concurrently negotiate who should and should not belong to that place politically. When a random space becomes a distinctive place for its inhabitants, whom to cast out of that place becomes a valid point (Hopkins \& Dixon, 2006; p.174-175). Because group identity is revealed within place talk, it would not be wrong to claim that studying place talk tells something both about the subject (based on her/his one-on-one relationship with place), group relations (because places imply communal ties), and politics (claiming and defining a place socio-politically).

In the present study, squats are specifically selected as the political place that harbour a certain type of collective action. Squatting as a collective action can be mainly defined as occupying an empty dwelling and politicizing it via certain values by the people opposing the system (Prujit, 2013); and squats are the objects of this action. This study takes an urban political squat to its centre because it is assumed that this is the perfect ground in which to catch both individual aspects and group relations at the same time. The main point of curiosity is to understand how individual aspects (such as subject's political position) intervenes in collective identity that is formed within the collective action itself (Taylor \& Whittier, 1995).

This study grounds itself around a common space that is constructed by ideological, cultural and political determinants. It does this purposefully, to (1) prove how a place synchronizes with the action itself as in norms, values and idioculture, and (2) to understand how place framings might be useful to show how unsynchronized the group relations can get. Thus, the main assumption is that a squat (a place that is both a symbol of 
the collective action and a canvas which immediately shows the repercussions of every individual intervention) would be the variable that enables the study of both the personal and the collective through place belongingness/identity.

Being the first successful example of urban political squatting within the new social movements paradigm in Turkey, the Don Quijote Social Centre in Kadiköy has attracted a lot of attention as a research topic (Doğanay, 2016; K1c1, 2015; Kühnert \& Patscheider, 2015; Özçelik, 2019; Özdeniz, 2016; Rittersberger-T1lıç, 2015; Sağlam, Öztürk, $\&$ Kaçar, 2019). These articles on the Don Quijote Social Centre usually express how much of a breakthrough it is both in the local and global political arena, and summarize its key elements like organizing an alternative culture, maintaining autonomy, changing neighbourhood relations etc. Thus, they serve as introductory while also focusing on the fields of political science and urban studies (Özçelik, 2019; Özdeniz, 2016). Although the present study shares the background and inside knowledge that led other studies, it claims -as far as is known- to be the first social psychological academic publication on this topic that studies identity positioning and place framing through the accounts of actual participants. Doğanay's (2016) study, for example, more or less adapts the same data gathering method (through observations and interviews) and emphasizes how the individual intersects with the public within the new social movements paradigm; however, the main focus is still introducing Don Quijote to the world's new alternative political arena and highlighting its achievements. ${ }^{1}$ Not only in Turkey but in the global arena too, studies on squatter movements predominantly focus on the incident's front stage; how squatters successfully claim an urban space and negotiate (with authorities). One has to dig really deep to find studies that focus on internal relations, paradoxes, and contradictory needs within a squat (see De Moor, 2016; Kadir, 2016).

This study on the other hand, aims at a more critical perspective and tries to see the relation between identity, place, group relations and political action through a discursive social psychological lens. It focuses on in-group relations among squatters in order to highlight the heterogeneity of voices. Although the findings are discussed on a political

1 Gülen's (2016) study on a different squat example in Turkey (Caferağa, Kadikoy) perfectly presents both the successful and problematic sides of this commoning experience. (For additional knowledge on squatting within Turkish literature; see Gürler and Gürler's book (2016): Karş1-işgal: İşgal hareketleri ve özyönetimler üzerine bir derleme). Gülen (2016) refers alignments and conflicts inside the squat and exemplifies them with extracts. Although both study have substantially similar findings, this present study specifically focuses on identity and group relations. 
level, such as what the political outcomes of heterogeneity might be, the main aim is to show this heterogeneity in accounts of actual participants of the squat, in rhetorical agency. Moreover, this study depicts a very specific summary of the potential problems of experiences of commoning (for literature on commons, see Walljasper, 2010); thus, it aims to initiate a debate for future studies.

Overall, the main curiosity is whether the people who built the Don Quijote Social Centre as a collective place formed a collective identity despite their conflicting (political) positions. The results of this study clearly showed that place is politicized through its subjectification and through pre-existing social identities.

\section{Collective Action Accounts}

Identity making is a common process in collective actions since they involve, produce and change social identities, and political actions are grounds for intersections of different identities (Kelly, 1993; Reicher, 1984; Taylor \& Whittier, 1995). When pursued through a discursive approach, the study of collective action participation involves the rhetorical and linguistic tools used for legitimating the action. As an example of discursive research on identity and collective action, Reicher and Potter's (1985) study sheds light on how differently an uprising can be explained by the members of different groups. Potter and Reicher (1987) found that the same action was narrated differently by opposing groups and the same word ("community") was used in different contexts implicating different meanings.

Social identities can be used as legitimization tools for political actions (Reicher, 1984), thus tactical usage of identities in accounts of collective action participants is another field of research. Poletta and Jasper (2001) show that participants in a movement can include identities within their accounts in both a highly strategic and context-appropriate way, depending on how they want to be represented. Although idiosyncrasies of everyone is commonly presupposed in contemporary collective movements, Bernstein (1997) proves that activists highlight this notion very conditionally. Many times, convergence rather than divergence with majority is, strategically, underlined. In other words, despite their non-mutual aspects with the majority (be it the rest of the neighbourhood, or other citizens, or lay people) activists purposefully try to de-marginalize themselves and point out how similar they are to the rest of the people. In this paper, these strategic accounts of squatters are not highlighted (although they prove Bern- 
stein's point) because the main interest is to investigate the in-group relations of squatters; for example, how participants of the same action talk about each other.

Fine (1995) suggests that every collective movement evolves around its participants' interactions and that these create the movement culture and vice versa. This phenomenon is best studied in relation to collective action frames (Benford, 1987; Benford \& Snow, 2000; Snow, 2004). When utilizing collective action frames, actions are positioned within a frame and transmitted as such to the listener. Idioculture of the movement equips its participants with specific communicative and behavioural practices as well as with a moral ground (including rights and responsibilities). Collective action frames also reveal a constructed reality; this reality narration involves the voice of protagonists as well as antagonists and the sociopolitical background of the movement (Snow, 2004).

This present study aims to investigate whether and how the individuals under the roof of the same collective action, come up with alternative narratives about the same debate topics. Herein, rhetorical agency is introduced as an analytic unit. Individuals are rhetorical agents when they present tactical accounts based on how they want to represent things, produce alternative narratives contrary to preponderant discourses, and organize their talk in favour of desired result, a perlocutionary act. It is that kind of agency, a speech act, which underlies collective action frames. Relating things to each other purposefully, positioning subjects, and making use of cultural and ideological backgrounds in every action frame creates an alternative reality (Benford \& Snow, 2000), and this phenomenon is studied under the notion of rhetorical agency.

As squats are the objects of squatting action, they carry the same idioculture of the movement. The place of the movement works as a micro field where all different kinds of people meet and interact. Thus, spatialized politics permit the study of Benford and Snow's (2000) concept of frames through analyzing how actors talk about the place that is embedded in the movement. This being the case, it now becomes important to discuss the notion of place identity.

\section{Place Identity}

Identity positions the individual within a social context (Howard, 2000, p.371). As for places, they not only serve as stages for events but they also become a part of self (Dixon \& Durrheim, 2004). 
"Place fosters a common identity, based on common experiences, interests, and values (...) place provides an important mobilizing discourse and identity for collective action, one that can obviate diverse facets of social identity in order to define a neighbourhood-based polity" (Martin, 2003, p.730). According to Dixon and Durrheim (2000) identifying with a place brings forth social identities since all places are basically composed of two groups: inhabitants and outcasts. Thus, place identification can be described as being part of a certain group that is defined by values attached to a place. Basically, place identification is a political process.

Social psychological studies on place identity usually focus on belongingness of home, neighbourhood, or city (Cuba \& Humon, 1993; Lindstrom, 1997; Mason, 2004; Taylor, 2010). When there is a shift from private to public places social psychological inquiry gets involved with politics. Neighbourhood based organizations are a good example to see how actions and collective identity practices are positioned with reference to a specific place. Martin (2003) studies neighbourhood-based organizations' collective action frames and discovers how actors frame the place in order to justify their actions and themselves. "Place frames conceptually identify this relationship between place and activism by situating activism in place (...) Studying place frames provides the conceptual framework for understanding how community organizations create a discursive place-identity to situate and legitimate their activism." (Martin, 2003; p.733).

Although a squat is a dwelling with bordersit can be said that it is not a private place. The aim for it is to be both public and owned by everyone, yet by no one. Squatting a place involves spatialized identity politics as well as initiating an identity struggle that is directly connected to the place itself. That is the reason why squatters' accounts are full of place framings; actors try to define the squat and its scope. This means that the squat has to be defended primarily before anything else because all that is advocated is ascribed to that place.

Because the main interest of this study is the encounters of subjective and collective within collective action, new social movements are an excellent ground to ask how individual differences merge with group identification in this era of postmodern politics.

\section{Squatting as a New Social Movement}

The tag postmodern politics follows the 1980's when gender, ethnicity, race and subject positions-based movements gained weight. Marginal groups and individuals found 
support in postmodern theory to underline the specificity of their positions and the differences that exist between them and other groups or individuals. Basically, what is meant by postmodern politics is "identity politics" and also "politics of difference" (Best \& Kellner, 1991; p.205).

At the beginning of twentieth century the Marxist labour movement was at its peak. European theoreticians who believed that the course of collective movements took a turn in the late 1960's, during the beginning of post-industrialism and the information age, created a new sociological research paradigm called "new social movements" (Touraine, 2002). In the mainstream Marxist labour movement the "plural nature of social groups were subsumed to a class alliance (Lenin) or a historical bloc (Gramsci) that is governed by the working class" (Best \& Kellner, 1991; p.194). On the other hand, new social movements created new forms of resistance and antagonisms and "new political identities that are irreducible to class positions and productivist logic." (Best \& Kellner, 1991 ; p.194). From then on, it went beyond the problem of uneven redistribution of resources and extended its borders to problems about quality of life, the right to choose, freedom for different lifestyles, a democratic decision-making process allowing for citizen participation, and places of collective solidarity above bureaucracy and relations of production (Pichardo, 1997). Autonomy and lifestyle are cherished in these types of movements and for that matter every corner of daily life is open for politics, be they politics of identity, culture or public.

"The postmodern celebration of plurality and multiplicity facilitates a more diverse, open, and contextual politics that refuses to privilege any general recipes for social change or any particular group" (Best \& Kellner, 1991; p. 286). However, as might be expected, the more idiosyncrasy and plurality are emphasized the more unlikely a chance of collective will and action occurs (Burr, 1998, p.17). Yet, although identity and difference are two seemingly irreconcilable concepts, an identity politics still might emphasize the effects of them and how important it is to recognize the numerous, different and specific political groups that actually forms one's political identity (Best \& Kellner, 1991; p.207).

This emphasis on plurality and difference makes postmodern politics a target of criticism because it might be mistaken for liberalism from time to time. Moreover, it becomes legitimate to ask whether we are "to accept all voices as espousing equally valid claims? If not, then how do we discriminate between them?" (Best \& Kellner, 1991; 
p.289). Similarly, Touraine (2002) asks himself how "new" those new social movements are, as he recognizes their failure in overcoming the old, Marxist, Leninist ideologies. Touraine (2002) points out that neither anti-capitalist nor anti-globalization movements can be social enough as long as they keep lacking the capacity to lift the predominance of political over social conflicts; and keep falling into trap of "liberation theology" ( $p$. 93). For Touraine fighting against top decision makers or economic networks will not mean anything unless a civil society is empowered through agent social actors.

In the light of these points, the present study deals with a proper example of new social movements. Squatting is accepted among new social movements based on its informal model of organization, horizontal decision-making process, primarily middle-class participants, and cultural and political embedding (Prujit, 2013). As a sub-branch of the Occupy! Movement, it can be described as occupying buildings/dwellings which are abandoned, desolate or empty for a long duration of time, by a group of people who have no legal right over that residence. Squatting a dwelling generally establishes a political response to all kinds of social and economic irregularities. Squatters might want to draw attention to an unfair distribution of economic resources, problems in attaining a decent dwelling, corrupt urban planning, a better society, or maybe just to their opposing political and cultural stances (Prujit, 2013). The Occupy! movement adopts a DIY (do it yourself) culture and disregards the present state and its institutions. Aiming for total independence, these local movements try to liberate everyday life practices from the grip of capitalism and build a so-called desired future, starting from today.

Repeating the slogan Reject-Reclaim-Reconstruct, squatting actions originate both from a felt discomfort against the regime and a need for better housing. Squats are ideal social spaces for alternative lifestyles, activities of co-production and commune living. Another important characteristic of these spaces is their openness to differences, new ideas and alternatives. Squat behaviour is both regulated and lawless, and its keywords are anarchism and autonomy (Martinez, 2007; Squatting Europe Kollective, 2013).

\section{Turkey's Most Prominent Squat: The Don Quijote Social Centre}

The act of squatting by the poor and by migrants due to the need for housing and accommodation is a well-known topic in Turkey as the concept of gecekondu has existed since the 1950's. Aside from shanty-towns, there are also examples of political commune experiences (village communes in Viranşehir, Fatsa, Hakkari, Dumanlıdağ) and occupa- 
tions of mines, factories, lands, soil, universities and a movie theatre, all of which took place long before the Gezi Park Occupation. However, as a means of collective uprising, the occupation of Gezi Park in June 2013 has most certainly brought forth a shift towards a place-based resistance. Moreover, the Gezi movement introduced a non-hierarchical organizational system among its participants which was an attempt to embrace the heterogeneity of people involved in Turkish politics, and with that the concept of new social movements entered Turkey (Eskinat, 2013; Gambetti, 2014; Göle, 2013; Y1ldırım, 2014). Another important impact of the Gezi movement is the localization of solidarity. After police forces closed off access to Gezi Park, people continued to gather in neighbourhood forums (mainly in parks) to discuss issues such as local democracy and citizen engagement. The Rasimpasha (Windmill) Neighbourhood in Kadikoy district formed its own neighbourhood organization called the Windmill Solidarity. On 29 August 2013, with autumn approaching at the door, Windmill Solidarity came up with the idea of squatting in a four-storey building that had been vacant for more than twenty years at Duatepe Street, and thus Turkey saw its first collective squat since the occupation of Gezi Park.

Until its evacuation ${ }^{2}$, Don Quijote was a place for meetings and events for various groups of people, and the people who were responsible for the place passed the duty on to incoming groups as time went by. These transitions were not sharp. Different social and political groups cohabited in the squat, like the people from Windmill Solidarity, inhabitants of Windmill neighbourhood, independent artists, Erasmus students, anarchists, large and small components of the Gezi movement, supporters of dissident parties like the Republican People's Party (CHP) and the People's Democratic Party (HDP). They all took part in the squat simultaneously. When the number of members of the involved groups decreased, remaining groups took over the responsibilities. The running of the squat and its needs was handled through organization. The decision-making was carried out at forums that were held at intervals and planned publicly via Don Quijote's Facebook page. Putting a decision into practice needed nothing but the majority of votes.

Because Don Quijote had been planned to be used as a social centre at the very beginning, the topic of sheltering remained the main subject of debate at forums until it was unanimously decided on May 2015 that the accommodation of up to two people

2 At the beginning of November 2015, the Don Quijote Social Center was cleared out by municipal police forces after the legal owner of the deed intervened. Until now it still remains the only squat that has been sustained for the longest duration. 
was permissible on the condition that the duration of stay should be no longer than three months. The only required qualification expected from the inhabitants was to follow Don Quijote's basic principles. These were independence, equality, fraternity, freedom, non-ownership, a spirit of sharing, cultural, scientific, artistic productivity and creativity, love of nature and all living creatures, opposition to all sorts of violence and exploitation, opposition to discrimination based on class, race, species, breed, nation and gender. Although squats typically stand for non-ownership (Prujit, 2013), collective ownership as a transition experience to non-ownership is also acceptable to worldwide examples of squatting (Squatting Europe Kollective, 2013). Collective ownership was also practised at Don Quijote as the key to the dwelling was owned and shared by certain people. Other than that, anybody was welcomed until midnight. ${ }^{3}$

Based on this, the analysis follows the following three main research questions:

1) What are squatters' common arguments on the Don Quijote Social Centre?

2) Despite common arguments, do place frames differ based on different subject positions of squatters? If they do, how does this show itself in talk?

3) Through which discursive acts do squatters position themselves and other squatters?

\section{METHOD}

\section{Participants}

Individuals who witnessed different periods of the Don Quijote squat and who were responsible for the place for some time were contacted via Facebook and selected using snowball sampling. Those who agreed to participate were interviewed after Don Quijote was shut down.

With an average age of 34, 13 individuals (three females, ten males) were interviewed for an average of 60 minutes using in-depth, semi-structured interviews. These individuals came from different professions (visual arts, private tutoring, construction, advertisement, digital marketing, income management), educational levels (undergraduate to graduate degree), and political views (anti-political ${ }^{4} /$ unorganized, socialist, com-

3 This information is based on the field study that was held pre-analysis. Data were analyzed after needed information (key rules, event organization process, key people in charge) about the squat was gained.

4 This term was asserted by the researcher to define participants who were unwilling and against to describe themselves under a political view or party. Except this term, all political views and identities were raised by participants themselves. 
munist, Marxist, anarchist, leftist, anarcho-communist) In order for the data and study to be rich and valid, variation among participants, based on their political views, was taken into consideration. Here, the extracts are separated into two main conflicting groups between organized and unorganized/anti-political individuals.

\section{Instruments}

The data consist of nine online sources (public announcements ${ }^{5}$, news sources ${ }^{6}$, a mini documentary ${ }^{7}$, and studio interviews ${ }^{8}$ that introduce Don Quijote to the public), a month of field study in and around Don Quijote, and transcripts of 13 face-to-face interviews with actual initiators of Don Quijote.

The interviews consisted of six main questions, in addition to questions about demographics (sex, age, education level, political view, relation to any political organization, the place of birth, duration of Istanbul residence, religiosity level), and participant's relationship with the Windmill Solidarity, duration of participation in the action (When did they decide to take part in the action? When did they become less involved with the place?), and main responsibilities within Don Quijote. The main questions about Don Quijote were as follows:

1) How would you describe Don Quijote?

2) How would you describe the people who visit Don Quijote?

3) How would you describe the political action that is related to Don Quijote?

4) When and how did you decide to become a part of the place? Could you explain the process?

5) What is the meaning of this place for you?

6) Why do you think Don Quijote was shut down?

5 https://www.facebook.com/YeldegirmeniDayanisma/posts/528081233951679

https://www.facebook.com/YeldegirmeniDayanisma/posts/564442290315573

https://www.facebook.com/groups/donkisotatolyeler/?post_id=1416201388661685

6 https://www.haberturk.com/gundem/haber/896453-don-kisot-kadikoyu-isgal-etti http://www.bantmag.com/magazine/issue/post/25/144

7 https://www.youtube.com/watch? $v=m S d Y V o K f Y I 8 \& i n d e x=5 \&$ list=LLqHPGgfyFyeUQqmS-bCRg0g

$8 \mathrm{https}: / /$ www.youtube.com/watch?v=ojYHM_Rk7XQ\&index=7\&list=LLqHPGgfyFyeUQqmS-bCRg0g https://www.youtube.com/watch?v=A5zONRZyJHw\&feature=youtu.be https://www.youtube.com/watch?v=FpXvyq1w9sg 
All interviews were semi-structured, hence each one of them had its idiosyncratic contextual ongoing. There were six main questions but additional ones (on some incidents inside Don Quijote, characteristics of different groups inside the squat, the problems within the squat, and the right solutions to those problems) were added based on the participant's answers.

\section{Procedure}

The data were collected chronologically based on three different time periods of the Don Quijote centre. Online sources belonged to the active phase of Don Quijote, basically between 2013 and 2014. Field study was carried out in April 2015. The interviews were conducted between November 2015 and September 2016, just after Don Quijote was shut down by municipal forces.

The first two data groups (online sources and field study) served as a pilot study in that they were introductory to the place; its physical construction, its familiar faces, how it is organized, its rules, main debate topics, incidents and problems within the squat. The third data group (the interviews) aimed to elaborate the in-group relations inside the Don Quijote centre and how problems were approached by alternating groups.

After the main interview questions were settled, people who had volunteered to become a part of this study were reached through Facebook. The field study had greatly helped to make acquaintance with the main actors and event organizers within the squat. Participants were separated into two groups (organized Leftists and anti-politicals), and members and non-members of the Windmill Solidarity were both counted in. Therefore, the people suggested by the main actors of both groups were taken into consideration and those people were reached through Facebook.

Semi-structured interviews with 13 volunteers began in November 2015 and lasted until September 2016. Right after each interview, transcription and first level analysis followed, and every bit of the results were used as directive during the interviews. After the interviews were completed, all transcriptions were analysed under the light of critical discursive psychology and the analysis process carried on until all results were refined.

\section{Data Analysis}

The analytical framework of this study is basically discourse analysis. By focusing on iterations, common argumentations, references, cause and effect relations, what is 
shown in the analysis is the fact that people make use of the same discursive repertoires when they perform a speech act (Taylor \& Wetherell, 1999). This study also adopts analytical units from critical discursive psychology and Positioning Theory.

Critical discursive psychology is useful in understanding why certain explanations are present at certain points during talk (Wetherell, 1998). Within this approach there are some key analytical tools, like argumentative repertoires. Simply described as the most frequent explanations shared by a group of people about a certain topic, argumentative repertoires are the linguistic manifestation of common-sensical knowledge (Edley, 2001).

During the analysis of argumentative repertoires, locating different explanations of people despite their usage of the same repertoire, is also important. Searching the reasons for similar and different explanations, the analyst looks for the rhetorical organization of speech (why is that talk organized that way), linguistic devices (word selection, metaphor, repair), and how participants make their actions and explanations accountable (Potter \& Wetherell, 1994). This study puts the notion of place in the centre, and studies which repertoires are drawn upon, while representing and accounting for Don Quijote.

Every repertoire involves social identities that are claimed, negotiated, or rejected. This phenomenon takes us to the notion of subject positions, another key concept in critical discursive psychology. Which repertoire indicates which position and how that position is represented are marked during analysis (Edley, 2001, p.211). Locating and understanding subject positions in relation to social identities is clarified by Positioning Theory. Positioning Theory (Harré, Moghaddam, Cairnie, Rothbart, \& Sabat, 2009) is a post-structuralist social psychological theory on identity which enables us to see how rights and responsibilities are distributed to different subject positions.

\section{RESULTS}

The headings used throughout the rest of this chapter represent the most common argumentative repertoires used while discussing Don Quijote. The extracts were selected to show two opposite poles within the same repertoire and two confronting frame structures.

\section{Squat as a Symbol/an Alternative}

The participants framed Don Quijote by pointing out certain place norms and values. Without exception, Don Quijote was always represented as an alternative to the state of 
affairs. Participants strictly marked that the place could never be the ultimate aim, rather it was a path to develop this alternative world which the participants dreamed of. Through this repertoire, the squatters made sure that the place per se was not the main thing that they stood for, rather the alternatives produced inside were. At this point accounts took different shapes because every participant defined what this alternative entailed in a different way, but Don Quijote was always framed as an alternative to neoliberal/capitalist system and centralized power. However, the subject position of the participant defined what was meant by the "alternative". In other words, place identity construction went hand in hand with subject position and the identity of the group which that subject claimed to be a member of.

I tell this all the time, if there is a place to have a gig, it is Don Quijote. If we are a band to show up at bars that has 15 Liras entrance fee or beer is for 20, we better not do this job. I said "Let's have a gig here once in a month." We made arrangements with Food Not Bombs organization. Here, that is the main deal of all this. This had to be the case at Don Quijote... Some will cook, some will make music and share with everyone... To me, that was the main purpose, I participated because I felt this way (...) The main purpose shouldn't be overthrowing the government, changing the governance; if it gets there, you stray away. The purpose should be doing good stuff, different stuff... Beautifying what you touch and see...That was our motto: "This place was horrible, we touched and beautified it." And we demand nothing from no one. (Extract 1, Participant \#9, anti-political, unorganized)

For participants similar to number 9 who did not position himself within any political party or identity, Don Quijote was an alternative social space where you can meet, produce and share together. Shared production and getting together without having to pay for things were framed as the main function of the place. Here, the analyst is introduced to oppositional groups and possible other identities that were present within Don Quijote when the participant defines a different way of defiance and politics of action, as when he proposes another possible way of creating an alternative to "overthrowing the government". That way he frames the place far from mainstream politics, simply as an independent and alternative space. Concurrently he constructs the corresponding group and place identity.

In opposition to the frame above, Participant 12 argued for a more disruptive way of politics in which Don Quijote symbolizes a way of living in line with communism that 
might downgrade and alarm the state. Through this place frame Don Quijote serves a more macro function than it can create as, merely, a social space.

I think the main thing is subversion and I want to be a part of a subversive political stance. An alternative opposing the government, disrupting the government...Umm I'm a Leninist you get it? (he laughs) Constructing social spaces is not my only concern, as is getting together with people. Among my concerns there is disrupting the government, there is organizing the alternative... Those social spaces don't serve these purposes unfortunately (...) We handled Don Quijote as Gezi's (Movement) continuation. I never handled it as something different. These were one whole; efforts to generate the good and the right. I am a communist and to me communism is the effort to build alternative alternative relations of production. Don Quijote was part of this. That's why we were there, to organize ourselves and communism as an alternative. (Extract 2, Participant \#12, member of Windmill Solidarity, communist/organized)

Unlike the first extract, this account represents the place and movement as a disruptive political act and positions Don Quijote in opposition to the state. The participant frames the place based totally on his political identity and draws a line between himself/ his group and other inhabitants of the squat who would define the place as a space for social gathering. Accounts like "we handled..."," we were there..." show that there was a certain group which he was a part of, and this group was in conflict with the other group's unpolitical framing of the same place.

In order to understand why being a Leninist was emphasized as such, one should remember the importance of a leading party in Leninist theory. The most decisive feature of Leninist theory is the importance and impact put on the communist party for organizing the solidarity of proletariat ${ }^{9}$. Party discipline mentality in Leninist thought is what gives birth to democratic centralism which contradicts anarchism and social democracy. In this example, the participant positions himself in opposition to other squatters who would define themselves as anarchists or anti-political. In this context the same usage of the word "alternative" now means organizing communism. The most interesting part is the resemblance of word selections by both participants, despite contrary place frames. In Extract 1, the actor puts "doing good stuff" as an opposition to disrupting the government. Meanwhile in Extract 2 disrupting the government is represented as "generating

9 See Lenin, 1918. 
the good". This shows how similar word usage might, rhetorically, serve different aims and meanings based on the narrator's subject position.

\section{An Orderly Place}

Another common account was that a squat necessitated "some" norms and order. All participants agreed on a basic structure within Don Quijote; a structure that worked as a mechanism that enabled running the place and keeping everything in order. The most underlined sources of problems were (1) the mobility and diversity of people within the squat, and (2) participation of people with different political stances. Participants present different solutions to the so-called problems that were both tested in reality and which should have been tested for a better outcome.

Along with the "orderly place" repertoire, the participants synchronously agreed on this already existing, a "should have" property of squats which is basically having endless freedom with no control, surveillance and hierarchy. This discourse of freedom contains a dilemma in itself: How is it possible to organize such a place where everyone is free to do whatever they want? Where, when and how to draw the line if control and surveillance is unacceptable? In point of fact, topics like clearance for entry, alcohol-tobacco intake, accommodation, and declaring ideologies within the squat had been debated for a long time at forums where different groups of squatters had difficulties achieving a consensus.

The interviews revealed that everyone supported the need of some kind of limit and structural frame to exist inside Don Quijote; yet the definition for the "red lines" and method of limits vary based on the subject position of the participant. On the "non-organized/anti-political" and "political/organized" scale, the participants who were closer to the latter pole seemed to be the ones who were the most pro-rules.

There was this debate on how to organize things. Let's make a black board; so that whoever is available can write their names on it. If programs overlap please communicate with one another because I don't want to be a moderator. Why would I be? If I have to be a moderator, this means hierarchy and I don't want it. When you say "This place has this kind of rules" I believe we build sets in front of people. If anyone acts contradictory, we could sit and chat and try to convince them. Let's not make rules because it would diminish our relations to people. For the time we were there we thought we could solve anything by communicating with people in a certain manner and style (...) There 
was a group who wanted to move along with some rules. What I observed was whenever they weren't in the place - This place lives... This place lives by itself and you ask "Why did this happen when I was away?" You were gone for 8 hours and you also know this place has to live. Things evolved to "How did you decide this event to happen here without our knowledge?" Well, we didn't decide. There is this principle; "everyone can do what they want, no one has to ask for permission" People might have acted based on this principle(...). (Extract 3, Participant \#2, unorganized)

It is not a coincidence that this participant also framed Don Quijote as an alternative social space where people get together and enjoy and create things for free the way they like. Just like Participant number 12 did, he also made clear that there was a certain group which he belonged to ("For the time we were there..."), and he separated his group from the ones who were pro-rules. He argues where and how to limit freedom based on the type of place frame he finds suitable for Don Quijote. In fact, while he opposes the presence of rules, he also criticizes a certain group for enforcing these rules. He positions them as "hierarchy invokers" who put obstacles for a better communication with the future participants, and finally, to the worst position ever: "owners of the squat".

In the idioculture of squatting, one of the most repeated out-of-norm behaviours a squatter could employ is acting like you are the owner of the place. The reason why this participant uses the living being metaphor ("This place lives by itself") for Don Quijote is to underline the non-ownership rule and by this, dismissing the 'pro-rules'. This metaphor indicates an important rhetorical act as well. The participant talks as if the squat itself is alive and constructs the independence of the place as a fact, thus positioning the pro-rules team as contradictory to the place's nature. In this way, the opposite group is positioned as violating the rights of inhabitants to act however they like.

Although he discards the rules, he still does not present a limitless freedom. There is an ongoing debate on solving possible contradiction through a less rigid style of organization in which people can organize things without anyone's surveillance by simply communicating with each other or using a simple object like, a black board.

Walla Don Quijote made me say "Such a nice thing, this Leninism!” Really! I thought Leninism is our salvation. Because it is such that you make something and it is gone after one week. Why? Because "Everything is by itself" ... This "by itself" method is not that successful most of the time. We couldn't make them understand that here is a social cen- 
tre; someone from the neighbourhood should feel comfortable here. If we wish to sustain it, Don Quijote has to have a user guide. We avoid saying "rules" but it has to have rules too. Rules are not so bad, they keep the place sustainable...Freedom, autonomy don't work like this. There's got to be a rule. That was the biggest issue and we couldn't convince them... Kit-kin we love them as friends but politically (laughs) no please! It exhausted me. When you don't lock the place, it turns out to be a property of some group. To prevent this, to make it stay as commons; that rule, that key, that order was necessary.

(Extract 4, Participant \#6, member of Windmill Solidarity, radical leftist/organized)

Unlike the previous participant, Participant 6 tried to prove the legitimacy of having rules inside the squat, and he based his account upon commonality and sustainability of Don Quijote. As a radical leftist who had been in other organizations (like Participant 12) he positions himself as Leninist (like Participant 12) to embrace the rule of some group as necessity (like Participant 12 does). This is a great example of how the political action is subjectified while the place is being politicized. Farro and Thaler (2014, p.4) propose that people, more likely, tend to participate in political action if there is a web of relations to certify their prior beliefs and stances. As above, through the place itself, the participant proves to himself how politically impractical the other group and their anti-political stances are, and secures his position as a Leninist.

This account hints at how the participants who were closer to Windmill Solidarity (Participant 6) tend to position their own group. For example, here, the group of libertarians, anarchists, or simply anti-political participants are positioned as less informed, less visionary, and politically inapt, and their method of organizing things "by itself" was coined as unsuccessful. The interesting part is, again, how members from different groups construct diverse realities on the same subject using the same argumentative repertoires. The last two participants, despite their different subject positions, defended their stand by using the same owning the place repertoire. While the former, accused the pro-rule group of acting like they owned the place, this participant stood up for rules because they prevent others from owning the place.

Another important result is how the participant aims at conversational repair ${ }^{10}$. Trying to legitimize the presence of rules creates a dilemma that squatters face: proving a

10 If there is an incompatibility between the practice and the idioculture of the movement people tend to legitimize this discrepancy through speech acts (Snow, 2004; p. 398-99). 
negatively connotated thing (rules, for this context) as beneficial in reality. In other words, within the idioculture of such a movement as squatting that is based on autonomy, standing up for rules needs extra explanation for legitimization. That is why Participant 6 organizes his speech in such a way; as "We avoid saying "rules" but..."."

\section{A Space with Limited Ideology}

The third repertoire about place is the importance of having an ideology-free environment. Framing Don Quijote as self-directed serves the grand narrative of "a place (squat) owned by everyone; yet by no one". Without the inclusion of any certain ideology, Don Quijote can be a place where everyone from different backgrounds can gather and organize under common ideals.

Although participants fell under consensus on this issue, analysis reveals how participants from different backgrounds used this repertoire (1) to assert for a group's -so called- patronizing behaviour, and (2) to come clean from accusations of acting out of the interests of an organization.

Imposing an organization's politics and not being open to learning new things while claiming that place (squat) made things unfruitful. What we supposed to do there, in the first place, was not to create a discussion platform for the sake of a party or union. The main thing we worked for and dreamt for, -what was supposed to happen-was to lead to an ordinary citizen, someone who has no interest in politics, owning a public space as such. (...) You shut your doors; which is the main problematique in Turkish leftism... Trying to shape his people and society, based on the rigid centric ideals... They are (talking about the other group) related to a headquarter, this is where the trouble begins. They are linked to Ankara, let's say, and they tried to carry their politics here, to the neighbourhood. There are lots of commune attempts in our history but all of them get stuck at the point where some people impose rules and want the power for themselves. Carrying onto the phase of a collective mind becomes hard because we all have too much prejudice and too many beliefs and we impose them on each other. (Extract 5, Participant \#7, unorganized, anti-political)

This example goes beyond the criticism of a certain group and becomes a wholesome condemnation of leftists in Turkey. The participant, being an independent, aligned himself against pro-rulers; but he made it even more general and blamed the whole left ideology

11 "I am not...but..." types of speech acts are quite common when people talk about disapproved or politically incorrect things (Van Dijk, 1984, p.120). 
for it. While positioning the Turkish leftists as non-progressive and ambitious for power he, concurrently, draws a subject position for himself. Through picking a master narrative on Turkish leftist politics and generalizing the criticism to a "Turkish left" he makes the trouble look, seemingly, less personal and renders the problem more historical, fundamental and factual. While leftist people are categorized as being unable to break free from group identity and incapable of acting without the direction of a higher organization, they are also represented as the main barrier before the possibility of a "collective mind".

Framing the place as independent of any ideology and grounding this independence as a normative principle of squats is a rhetorical tactic; first, to dismiss the pro-ruler group as being incompatible with the squatter identity, and secondly to organize many people from various beliefs around Don Quijote. Needless to say, the participant's subject position matches up with his place frame. He subjectifies political action and the place while also politicizing it. Don Quijote becomes a tool to certify his prior beliefs and stance, this time, against radical leftism.

(...) They were telling us "You are trying to look cute to neighbours"; whereas we were doing something more revolutionary, in fact. We were standing out, right at the core of the system. Right from the beginning I am just opposing their method. Dialectics, right? Something was wrong with their method. Not that we are more revolutionist than they are, not that we are in a pissing contest. But- when do you evolve into a revolutionist? It takes years, right?! They tried to impose the knowledge straight away. This isn't the right way to organize. That's not how we (talking about his personal Marxist organization) got organized. The leader first built a humane interaction with me; then, he made sense. You don't persuade me when you go "Marxism is this and that." We need a long process to discuss first. (...) And within the solidarity (Windmill) there were all kinds of people, but they could be opposed altogether to a common problem, not because they were getting along perfectly. We, too, were opposed to a party propaganda when they were imposing decisions on the forum. They are the same, whether a party or a single person. Let's come up with something collectively. (Extract 6, Participant \#13, member of Windmill Solidarity, Marxist/organized)

This extract summarizes the group categorization. By using the comparison between the $u s$ and them it clearly puts how more organized leftists (mostly the members of the Windmill Solidarity) and anti-political and/or unorganized participants construct oppos- 
ing accounts. Although the comparison part was repaired by "not that we are in a pissing contest" line, the participant still positioned himself and his group as the more revolutionist ones, since they knew the proper method to organize people; moreover, they had the courage to build communism as an alternative right at the centre of a neighbourhood. These two reasons also are stated to negotiate the first-order positioning ("You are trying to look cute to neighbours") made by the other group.

By way of an answer to what had been said in Extract 5 (participant 7), Participant 13 sends the first-order positioning held against him and his group (that they are imposing their own politics) back to anti-political and unorganized persons. He counter-positions those people as the ones who were trying to impose an ideology, but with a wrong style; and he makes a second-order positioning for himself and his group as he stands by something more collective.

Rhetorical agency that is visible in the construction of alternative accounts, peaks especially when opposing participants counter-position each other, using each other's words. When he points at the importance of humane interaction as a way of organizing people who have no political build-up like the inhabitants of the neighbourhood, he uses Participant 2's words (See Extract 3). The first-order positioning that is made in Extract 3 towards the people in Windmill Solidarity (being unable to communicate with people, not knowing the proper manner and style to use in communication) is dismissed and sent back. He repositions himself and the organized persons as the ones who actually knew the way with things and who were trying to build a relationship with the neighbourhood. Stating that Windmill Solidarity was also against any party propaganda and claiming that one person's tyranny is also within the realms of possibility as likely as a tyranny of the majority ("the same; whether a party or a single person") are other examples of second-order and counter positioning.

\section{DISCUSSION}

Showing how people narrate different realities while talking through the same repertoire is the main purpose of the present study. The squatters' accounts reveal that although they talk out of the same repertoire they might still frame the place and action differently. These differences were basically linked to group identities and subject position (political identity mostly) of the actor. The findings revealed how place identity and place framing are constructed based on the narrator's identity. 
Actors not only talk through the guidance of idioculture of the movement, they also discuss and compare different political ideologies (Snow, 2004, p.399). Like Steinberg (1999) mentions, these accounts are not only a confrontation with the ideology of power but also a re-production of common-sensical knowledge and power discourse. This reproduction of customary social representations is intriguing considering this premise of a squat as a commoning place and squatting as a new social movement. Both written sources and accounts of squatters on squatting and squats present a picture of an alternative, a never-before ground; in such, old or mainstream ways of politics are long gone. Limiting ideology inside Don Quijote serves this narrative as well; the repertoire constructs a political space where ideology or political positions are no longer debated but people can still be activists. However, the emergence of political positions as social representations all over again within the accounts of squatters show us that while place is politicized it is done so through subject positions regardless of the idioculture of movement. Moreover, through a critical perspective against new social movements, the circulation of communist/Leninist discourses and the acts of legitimating these appear to affirm Touraine's (2002) concern that new social movements are bound to fail because they are still dominated "by an old ideology, a Marxist ideology, or even a Leninist ideology" (p. 92).

Positioning analysis is mainly used in daily, reciprocal interaction between two or more people. In every turn taking it is possible to see different stages of positionings. First-order positioning is when the speaker sets the ground for herself and others. This precedes second-order positioning which is the response and alternative positioning that the opposing speaker makes. While speakers negotiate their positions (deemed by opposing speakers) counter positionings carry on in every turn take, until the ground for conversation is settled (Harré et al., 2009). In this study participants talk back at the things that might have been said during the previous interviews with other participants. Thus, it is harder to see the positioning sequence. However, an interesting finding of this research is how interactive and polyphonic the accounts are. Although participants are solely interviewed there seems to be a dialogue held with a non-existent audience, especially in the recordings of actors from conflicting groups. Although participants are not talking to each other but to the interviewer alone, the results show that everyone makes a second-order positioning based on the assumed first-order positionings deemed by opposing group. 
The radical leftists and anti-political participants talk as if someone from the opposite group is listening or answering back. Both groups construct their accounts to negotiate the positions the other group has placed them in. Billig (1989, p.206) introduces the term argumentative discourse and proposes that all critical and justifying accounts are automatically argumentative. Actors not only frame the place; they also justify their political stance and legitimize their actions inside Don Quijote. That is the reason why conflicting realities appear even when they speak from the same repertoire.

\section{The (Im)Possibility of Constructing a Collective Identity}

The extracts show how impossible it is for participants to leave their defining social/ political identities behind while taking part in a collective action. However, the idioculture of squatting puts forth a collective identity: the identity of a squatter. The main reason for the conflict between accounts is because the definition of this collective identity is not settled. Members of the two confronting groups accuse each other of not being the "ideal" squatter. While leftists/organized ones/members of the Windmill Solidarity are positioned as destroyers of autonomy and creativity inside Don Quijote, the unorganized/anti-political actors are accused of behaving in a self-interested manner and not being in line with the majority. In short participants, based on subject positions, criticize the out-group members' compatibility with the -supposedly- uniting collective identity. In the meantime, they come up with conflicting accounts on place framing.

As has been shown, the confrontation is not only upon place framing or the definition of an ideal squatter, but also on different political identities. How different group members position each other is also a representation of group categories within Turkey's socio-political discursive arena. Moscovici (2001) defines social representations as "specific phenomena which are related to a particular mode of understanding and communicating - a mode which creates both reality and common sense" (p.33). Counter positions, like anarchists or leftists that arise in accounts as accusations, are in fact social representations because they do not reflect the reality but construct it at the actor's will. For example, although "there were all kinds of people within the solidarity" (See Extract 6), people in Windmill Solidarity are generalized and represented as leftists altogether because once in a while, a couple of people from the solidarity took sides with applying more rules inside the squat. Thus, the implication of the leftists is used to generalize people that are pro-rules. Likewise, the marker of the anarchists might not truly reflect whom the actor is positioning himself against, rather it reflects the social representations of anarchists within Turkey's socio-political discursive arena. 
Taylor and Whittier (1995) differentiate pre-existing social identities from collective identities that arise only from participation in collective action. All in all, the findings make us question the possibility of a new-born collective identity that unites all participants. It turns out there is more of a plurality and polyphony rather than a unitary $u s$ or we. For a uniting collective identity to occur, Reicher (1984) emphasizes the necessity of protesting against one unitary out group (like police forces). When there is a strict line between us and them, formation of collective identity is inevitable (Goodwin, 2001; as cited in Eyerman, 2007, p.50). In the present study although the neo-liberal system is set as the head evil, "system" per se is too intangible to be named as an out group. In that case it is not wrong to say that a tangible other is missing in this collective action. Being one under a unitary identity is uttered repeatedly; like a utopia or an ideal that could not get accomplished. On the other hand, there is certainly a formation of us versus them within the group of actors that shared the same place.

Moreover, the squatter identity is not a post-action construction; but rather an ideal frame to judge people accordingly, and based on the conflicting accounts, it is obvious that what is ideal has different definitions. The presumptions about who the ideal squatter is, are determined by the idioculture of the movement, global examples and within the place itself, through interaction and within context. Subject positions like political identities affect the definition of how an ideal squatter should act. Also, discrepancies on the ideal most certainly invite the formation of $u s$ versus them within in-group relations.

Considering the general motto which defines the place (owned by everyone yet no one) there occurs a discrepancy between the ideal and practice. Despite the norm of plurality and diversity that are common in new social movements, it is not wrong to say there is an ongoing argument on who should be let in and whom should be excluded from Don Quijote. Another discrepancy lies at the heart of horizontality which is, again, the very norm of alter-globalization movements (Maeckelbergh, 2012, p. 211), like squatting. Anti-hierarchical decision making via forums is the most popular practice of horizontality, yet in this example, diversity is the main reason for the impossibility of a consensus and therefore, the feeling of disappointment (Nunes, 2005). Participants who were experienced in organized politics and who were closer to leftism particularly tended to relate such problems to horizontality. 
Within new social movement studies, problems like the impossibility of forming a collective identity or discrepancies between the ideal and practice are always debated. To open a gateway for solution, Nunes (2005) warns about the fetishized horizontality that is worshipped as a model and applied whatever the circumstance is. However, for greater outcome, horizontality should be accepted as nothing but a practice that is open to discussion and alteration. The same thing applies to the celebration of plurality and multiplicity. One should not valorise micro-politics, plurality and multiplicity per se, without a critical standpoint to what is actually implied (Best \& Kellner, 1991; p. 299).

For the lack of a unitary identity to gather under, Fominaya (2015, p. 66-68) proposes another form of identity that is indigenous to new social movements: autonomous collective identity. In this way of thought, the idea of a unitary group tag that includes everyone is criticized. McDonald (2002) argues how everyone is so accustomed to thinking inside the orthodox paradigm of collective identity in which solidarity is cheered by everyone as a norm. Yet, modern collective movements are full of shared oppositions of different individuals and this diversity gives way to fluidarity instead of solidarity. When such conflicts are blocked out there is a probability of an authoritarian tune in which different perspectives are left unnoticed (Bishop, 2004; p. 66). Thus, letting the diversity speak for itself is what keeps these political outbursts as experiences and ways to learn from mistakes.

Overall, the results show that the norms of squatting and squats are yet to be debated; also, in Turkey. The analysis discussed reveals (1) common-sensical knowledge in Turkey based on different political identities, (2) place identity that is imposed by actors, and (3) the relation between the imposed and subjective identity. It is clear that the actors frame place based on their subject positions, and different positions result in alternative reality constructions. Leaning especially on two different group accounts, the study reveals what subjective political action entails and how place is politicized.

From a critical perspective the analysis puts forth two things : (1) Rhetorical agency creates the ground for individuals to make politics, and (2) to what extent it is all right to talk about an alternative social movement here. While participants are opposing and arguing against the capitalist discourse of neoliberalism, they act in line with the idioculture of the movement. However, they simultaneously struggle to elude themselves from reproducing same old social representations that should belong to mainstream ways of 
politics. This of course should not be understood as a detraction of neither the movement nor the actors in it. What is aimed here is to bring up the possibility of maintaining collectivity while not withholding the heterogeneity of voices, for discussion.

The research observes a place-based political action right from within, by focusing on accounts about the so-called problems going on inside the place. New social movements or local autonomous attempts in Turkey (Doğanay, 2016; Gambetti, 2014; Kühnert \& Patscheider, 2015; Rittersberger-T1lıç, 2015; Yıldırım, 2014) are generally studied as rare and successful examples; usually their inner problems are not thoroughly examined with a critical manner. This study on the other hand, focuses on the conflictual side of the movement while also showing its similarities with worldwide alter-globalization movements. Critical discursive analysis helps to see the broader aspect, like how different political stances like anarchism or leftism are positioned in this geography's common-sensical knowledge.

Last, but not least, these results reflect a local attempt of a movement that has been experienced and challenged at various times in the global realm. First of all, they make claims neither about the whole movement nor about the Don Quijote Social Centre as a whole. Rather, they depict main argumentations on the problems within a squat; problems that were manifesting themselves more frequently as the time of the evacuation of the building approached. Secondly, although the main focus is on conflicting ideas in order to understand the intervention of in-group conflicts into the possibility of collective identity formation, those observations are not to denigrate the whole experience and the lessons it withholds. Considering the heterogeneous nature of horizontal movements such as this, the results are not to present this squat example as unsuccessful but rather to maintain a critical eye.

Peer-review: Externally peer-reviewed.

Conflict of Interest: The authors have no conflict of interest to declare.

Grant Support: The authors declared that this study has received no financial support.

Hakem Değerlendirmesi: Dış bağımsız.

Çıkar Çatışması: Yazarlar çıkar çatışması bildirmemiştir.

Finansal Destek: Yazarlar bu çalışma için finansal destek almadığını beyan etmiştir. 


\section{References/Kaynakça}

Benford, R. D. (1987). Framing Activity, Meaning, and Social-movement Participation: The Nucleardisarmament Movement. Doctorate Thesis. Texas University, Austin (USA).

Benford, R. D., \& Snow, D. A. (2000). Framing processes and social movements: An overview and assessment. Annual Review of Sociology, 611-639.

Benwell, B., \& Stokoe, E. (2006). Discourse and identity. Edinburgh University Press.

Bernstein, M. (1997). Celebration and suppression: The strategic uses of identity by the lesbian and gay movement. American Journal of Sociology, 103(3), 531-565.

Best, S., \& Kellner, D. (1991). Post-modern theory: Critical interrogations. New York: Guilford Press.

Billig, M. (1989). The argumentative nature of holding strong views: A case study. European Journal of Social Psychology, 19(3), 203-223.

Bishop, C. (2004). Antagonism and relational aesthetics. CUNY Academic Works, 51-79.

Burr, V. (1998). Overview: Realism, relativism, social constructionism and discourse. In I. Parker (Ed.), Social constructionism, discourse and realism (pp.13-26). London: Sage Publications.

Cuba L., \& Hummon D. (1993). Constructing a sense of home: Place affiliation and migration across the life cycle. Sociol. Forum, 8, 547-72.

De Moor, J. (2016). Practicing openness: Investigating the role of everyday decision making in the production of squatted space. International Journal of Urban and Regional Research, 40(2), 410424.

Dixon, J., \& Durrheim, K. (2000). Displacing place-identity: a discursive approach to locating self and other. British Journal of Social Psychology, 39(1), 27-44.

Dixon, J., \& Durrheim, K. (2004). Dislocating identity: Desegregation and the transformation of place. Journal of Environmental Psychology, 24(4), 455-473.

Doğanay, G. (2016). The Scope of the Occupy Movements in Europe and the Case of Turkey: Don Quixote Squat Avrupa'da işgal hareketlerinin kapsamı ve Türkiye örneği: Don Kişot Sosyal Merkezi. Siyasal Bilimler Dergisi, 4(2), 91-112.

Edley, N. (2001). Analysing masculinity: Interpretetive repertories, ideological dilemmas and subject positions. In M. Wetherell, S. Taylor \& S. J. Yates (Eds.), Discourse as data: A guide for analysis (pp. 189-228). London: Sage Publications.

Eskinat, D. (2013). Gezi Park: Negotiating a new left identity. Insight Turkey, 15(3), 45.

Eyerman, R. (2007). How social movements move. In H. Flam \& D. King (Eds.), Emotions and social movements (pp. 41- 57). Routledge.

Farro, A.L., \& Thaler H. (2014). Subjectivity and collective action. In A.L. Farro, H. Lustiger-Thaler, \& E. Toscano (Eds.), Reimagining social movements: From collectives to individuals (pp. 1-15). Ashgate Publishing, Ltd.

Fine, G.A. (1995). Public narration and group culture: Discerning discourse in social movements. In H. Johnston \& B. Klandermans (Eds.), Social movements and culture (pp.127-144). University of Minnesota Press.

Fominaya, C.F. (2015). Autonomous social movements and the paradox of anti-identitarian collective identity. In A. McGarry \& J. Jasper (Eds.), The identity dilemma: Social movements and collective identity (pp. 65-84). Temple University Press.

Gambetti, Z. (2014). Occupy Gezi as politics of the body. In U. Ozkirimli (Ed.), The making of a protest movement in Turkey:\# occupygezi (pp. 89-102). Palgrave Macmillan: UK.

Göle, N. (2013). Gezi-anatomy of a public square movement. Insight Turkey, 15(3), 7-14. 
Gülen, H. (2016). Mahalle ve aktivizm: Caferağa Dayanışması ve Mahalle Evi deneyimi. In D. Gürler \& A. S. Gürler (Eds), Karşl-işgal: İşgal hareketleri ve özyönetimler üzerine bir derleme (pp. 5798). Siyah Beyaz Kitap.

Harré, R., Moghaddam, F. M., Cairnie, T. P., Rothbart, D., \& Sabat, S. R. (2009). Recent advances in Positioning Theory. Theory \& Psychology, 19(1), 5-31.

Hopkins, N., \& Dixon, J. (2006). Space, place, and identity: Issues for political psychology. Political Psychology, 27(2), 173-185.

Howard, J. A. (2000). Social psychology of identities. Annual Review of Sociology, 26, 367-393.

Kadir, N. (2016). The autonomous life?: Paradoxes of hierarchy and authority in the squatters movement in Amsterdam. Manchester University Press.

Kelly, C. (1993). Group identification, intergroup perceptions and collective action. European Review of Social Psychology, 4(1), 59-83.

Kıcı, S. (2015). Türkiye'de işgal evleri: Don Kişot Sosyal Merkezi örneği. Squatted Houses in Turkey: Example of Don Quixote Occupied Social Center. (Unpublished Bachelor's Thesis). Mimar Sinan Güzel Sanatlar Üniversitesi .

Kühnert, N., \& Patscheider, A. (2015). Gregor Samsa and Don Kişot fighting against windmillsSquatting in Istanbul as an attempt to resist neo-liberal urban politics. Retrieved from: http://www. kaee.uni-goettingen.de/mapping-istanbul/wp-content/uploads/2015/06/SQUATTING.pdf

Lenin, V. (1918). The State and Revolution. Lawrence \& Wishart, UK.

Lindstrom, B. (1997). A sense of place: housing selection on Chicago's North Shore. Sociological Quarterly, 38, 19-39.

Maeckelbergh, M. (2012). Horizontal democracy now: From alterglobalization to occupation. Interface, $4(1), 207-234$.

Martin, D. G. (2003). "Place-framing" as place-making: Constituting a neighborhood for organizing and activism. Annals of the Association of American Geographers, 93(3), 730-750.

Martinez, M. (2007). The squatters' movement: Urban counter-culture and alter-globalization dynamics. South European Society and Politics, 12(3), 379-398.

Mason, J. (2004). Personal narratives, relational selves: Residential histories in the living and telling. The Sociological Review, 52(2), 162-179.

McDonald, K. (2002). From solidarity to fluidarity: Social movements beyond 'collective identity'--the case of globalization conflicts. Social Movement Studies, 1(2), 109-128.

Moscovici, S. (2001). Social representations: Essays in social psychology. NYU Press.

Nunes, N. (2005). Nothing is what democracy looks like. In D. Harvie (Ed.), Shut them down!: The G8, Gleneagles 2005 and the movement of movements (pp. 299-319). Autonomedia, New York.

Özçelik, D. (2019). Yeldeğirmeni'ndeki soylulaştırma sürecinin bir etnografisi. [An Ehnography of the Gentrification Process in Yeldeğirmeni Neighborhood]. (Unpublished Master's Thesis). Kadir Has University.

Özdeniz, D. (2016). Kentsel toplumsal hareketlerin kentlerin dönüşümüne etkilerinin değerlendirilmesi. [The Evaluation of the Effects of Urban Social Movements on Urban Transformations]. (Unpublished Doctoral Dissertation). Istanbul Technical University.

Pichardo, N. A. (1997). New social movements: A critical review. Annual Review of Sociology, 23(1), 411-430.

Poletta, F., \& Jasper, J. M. (2001). Collective identity and social movements. Annual Review of Sociology, 27, 283-305. 
Potter, J., \& Reicher, S. (1987). Discourses of community and conflict: The organization of social categories in accounts of a 'riot'. British Journal of Social Psychology, 26(1), 25-40.

Potter, J., \& Wetherell, M. (1994). Analyzing discourse. In A. Bryman \& R.G. Burgess (Eds.), Analyzing qualitative data (pp. 47-67). Routledge.

Prujit, H. (2013). The logic of urban squatting. International Journal of Urban and Regional Research, 37(1), 19-45.

Reicher, S. D. (1984). The St. Pauls' riot: An explanation of the limits of crowd action in terms of a social identity model. European Journal of Social Psychology, 14(1), 1-21.

Reicher, S., \& Potter, J. (1985). Psychological theory as intergroup perspective: A comparative analysis of "scientific" and "lay" accounts of crowd events. Human Relations, 38(2), 167-189.

Rittersberger-T1lıç, H. (2015). Squatting (in Turkey). In N. Konak \& R. Ö. Dönmez (Eds),

Waves of social movement mobilizations in the twenty-first century: Challenges to the neo-liberal world order and democracy, (p. 83-100). Lexington Books: London.

Sağlam, A. İ., Öztürk, A. Ç., \& Kaçar, A. D. (2019). Türkiye'de kamusal mekânın gelişimi. Development of the public space in Turkey. ATA Planlama ve Tasartm Dergisi, 3(1), 47-58.

Sarbin, T. (1986). Narrative psychology: The storied nature of human conduct. New York: Praeger.

Sarbin, T.R. (2005). If these walls could talk: Places as stages for human drama. Journal of Constructivist Psychology, 18, 203-214.

Snow, D. A. (2004). Framing Processes, ideology, and discursive fields. In D.A. Snow, S. A. Soule \& H. Kriesi (Eds.), The Blackwell companion to social movements (pp.380-412). Blackwell: UK.

Squatting Europe Kollective (2013). Squatting in Europe: Radical spaces, urban struggles. Brooklyn, Autonomedia.

Steinberg, M. W. (1999). The talk and back talk of collective action: A dialogic analysis of repertoires of discourse among nineteenth-century English cotton spinners. American Journal of Sociology, $105,736-80$.

Taylor, S. (2010). Narratives of identity and place. Routledge.

Taylor, S., \& Wetherell, M. (1999). A suitable time and place: Speakers' use of time to do discursive work in narratives of nation and personal life. Time \& Society, 8(1), 39-58.

Taylor, V., \& Whittier, N. (1995). Analytical approaches to social movement culture: The culture of the women's movement. In H. Johnston \& B. Klandermans (Eds.), Social movements and culture (pp.163-187). University of Minnesota Press.

Touraine, A. (2002). The importance of social movements. Social Movement Studies, 1(1), 89-95.

Van Dijk, T. A. (1984). Prejudice in discourse: An analysis of ethnic prejudice in cognition and conversation. Amsterdam and Philadelphia, PA: John Benjamins Publishing Co.

Walljasper, J. (2010). All that we share, a field guide to the commons. The New Press, New York, USA.

Wetherell, M. (1998). Positioning and interpretetive repertories: Conversation analysis and poststructuralism in dialogue. Discourse and Society, 9(3), 387-412.

Y1ldırım, Y. (2014). The differences of Gezi Parki resistance in Turkish social movements. International Journal of Humanities and Social Science, 4(5), 177-185. 